\title{
ВИНИКНЕННЯ ТА РОЗВИТОК ІНТЕЛЕКТУАЛЬНОГО ПРАВА В УКРАЇНІ
}

\author{
БАНЧУК-ПЕТРОСОВА Олена Вікторівна - - кандидат наук 3 державного \\ управління, доцент кафедри державного управління $і$ права Київського \\ національного університету культури
}

DOI:10.32782/LAW.2019.3.27

УДК 347.77(477)

У статті досліджено особливості виникнення та розвитку інтелектуального права в Украйні. Встановлено, що наразі система інтелектуального права в Украйні перебуває на етапі бормування. Нині в Украӥні простежується тендениія невпинного зростання кількості прийнятих нормативно-правових актів з тих чи інших питань інтелектуальноі власності. Однак, на жаль, далеко не завжди кількість відповідає якості. Виявлено низку проблем у вказаній сфері. Наведено комплекс рекомендачій щодо їх розв'язання. Визначено перспективні напрями подальшого розвитку інтелектуального права в Украӥні. Зокрема, зауважується, шьо подальший розвиток інтелектуального права в Украӥні має відбуватися за трьома основними напрямками, серед яких: розробка нової Концепчї ребормування державної системи правової охорони інтелектуальної власності в Україні та Наџіональноі стратегї розвитку сбери інтелектуальноі власності в Україні з урахуванням прорахунків та здобутків попередніх документів, а також міжнародних рекомендачій та зарубіжного досвіду; подальше удосконалення наиіональних нормативно-правових актів з питань інтелектуальної власності, узгодження їх положень між собою, усунення прогалин, приведення у відповідність до реалій съогодення та потреб украӥнського суспільства, систематизачія положень національних нормативно-правових актів з питань інтелектуальної власності шляхом прийняття розгорнутого закону про авторсъке право $і$ суміжні права; подальше узгодження положень начіональних нормативно-правових актів 3 питань інтелектуальноӥ власності із законодавством EC та приведення їх у відповідність до європейсъких, а також міжнародних норм та стандартів. Питання виникнення та розвитку інтелектуального права в Украйні потребує подальшого наукового дослідження у напрямку пошуку шляхів вдосконалення національного законодавства у иій сбері з метою удосконалення захисту прав інтелектуальної власності.

Ключові слова: право інтелектуальной власності, законодавство про інтелектуальну власність, інтелектуальне право, проблеми бормування, напрями подальшого розви$m \kappa y$.

\section{Актуальність теми}

3 кожним днем дедалі більшого значення у сучасному суспільстві набуває категорія інтелектуальної власності. Адже саме інтелектуальна власність є одним із наймогутніших стимулів розвитку науково-технологічного прогресу всіх галузей функціонування суспільства.

У даний час йде широка дискусія щодо перспективних напрямків подальшого розвитку системи інтелектуального права. Це обумовлює актуальність дослідження, насамперед, витоків виникнення інтелектуального права в Україні та його генезису. Адже подальше вивчення даного питання видається нам неможливим без дослідження історичної складової вказаної категорії. 


\section{Постановка проблеми}

Наразі в Україні напрацьована чимала законодавча база з питань захисту прав інтелектуальної власності. Проте нині чинне законодавство Україні у цій сфері не позбавлене недоліків. Унаслідок чого виникає чимало правозастовчих проблем, а судова практика залишається досить неоднозначною. Тому на сьогодні все ще залишається необхідність подальшого реформування законодавчої бази 3 питань інтелектуальної власності.

Нині на теоретичному рівні всіх наукових досліджень в Україні, зокрема юридичних, необхідно здійснити критичне оцінювання систем знань про інтелектуальне право в Україні, що вже сформовані, розглянути закономірності взаємозв'язку теперішнього й тенденцій майбутнього розвитку.

\section{Аналіз останніх досліджень і публікацій}

Право інтелектуальної власності є об'єктом значної кількості наукових досліджень. Зокрема, окремі аспекти цієї теми вивчали: Є. М. Гелеверя, К. С. Глушко, О. М. Головкова, А. М. Горнісевич, С. Дзюбіна, С. Ніколаєнко, Г. О. Швець, О. О. Аевінчук та ін.

Проте, попри внесок вітчизняних науковців у розробку цієї теми, маловивченим залишається питання виникнення та розвитку інтелектуального права в Україні. Крім того, останнім часом до законодавства, що регулює право інтелектуальної власності, було внесено низку істотних змін. Це, у свою чергу, обумовлює потребу відповідних наукових напрацювань.

Мета статті - на основі аналізу результатів загальнотеоретичних та галузевих досліджень, нормативно-правової бази з теми дослідження, з'ясувати особливості виникнення та розвитку інтелектуального права в України, виявити існуючі проблеми, а також запропонувати перспективні напрями подальшого розвитку.

\section{Виклад основного матеріалу дослідження}

Узагальнення літературних джерел 3 теми дозволяє стверджувати, що поняття інтелектуальної власності з'явилось досить давно. Значення творів літератури та мистецтва визнавалося ще за часів Стародавньої Греції [3].

Загалом, генезис правової охорони інтелектуальної власності в науковій літературі розглядають через призму поділу на такі чотири етапи: 1-й етап - зародження (період Античності III ст. до н.е. - II ст.); 2-й етап становлення (період Середньовіччя V-XVII ст.); 3-й етап - розвиток (період Нового часу XVII-XIX ст.); 4-й етап - удосконалення і приведення у відповідність з соціально-економічним та політичним розвитком (з XIX - дотепер) [4, с. 97].

Водночас узагальнення теоретичних напрацювань та аналіз правового підгрунтя щодо виникнення та розвитку інтелектуального права в Україні свідчить про те, що національну систему правової охорони інтелектуальної власності було закладено ще 3 часів здобуття незалежності. Першим тогочасним законодавчим актом у сфері правової охорони промислової власності незалежної України було «Тимчасове положення про правову охорону об'єктів промислової власності та раціоналізаторських пропозицій в Україні», затверджене Указом Президента України від 18 вересня 1992 року. Цим положенням запроваджувалася єдина форма правової охорони винаходів та промислових зразків - патент [12, с. 8].

У цілому, Україна, з моменту набуття незалежності і до нині, пройшла три етапи виникнення та розвитку інтелектуального права: на першому етапі було розроблено фундамент для інтелектуальної власності; на другому - прийнято міжнародні стандарти; на третьому - розпочато формування власної стратегії [1, с. 147].

Наразі наша держава перебуває на шляху реформування власної системи права інтелектуальної власності (інтелектуального права). Попри те, що Україна є учасником всіх основних (базових) загальновизнаних міжнародних договорів у сфері охорони інтелектуальної власності, вітчизняне законодавство у цій сфері сформоване далеко не в остаточному вигляді.

Україна є учасницею 20-и з 22-х чинних міжнародних договорів 3 питань інтелекту- 


\section{Дискусії, обговорення, актуально}

альної власності, функції адміністрування яких виконує Всесвітня організація інтелектуальної власності ВОIВ [5, с. 51]. I наразі законодавство України про інтелектуальну власність у цілому відповідає світовим стандартам або наближається до них [14, с. 123]. Водночас воно все ще потребує перегляду та удосконалення.

Нині в Україні простежується тенденція невпинного зростання кількості прийнятих нормативно-правових актів 3 тих чи інших питань інтелектуальної власності. Однак, на жаль, далеко не завжди кількість відповідає якості. Радше навпаки.

Так, зокрема, чинна редакція закону «Про авторське право і суміжні права» була прийнята ще у 2001 році. Втім, попри це, положення цього акта й досі у повній мірі не узгоджені з відповідними нормами Цивільного кодексу, що набув чинності в 2004-му.

3 огляду на вказане, цілком логічною видається розробка нової редакції закону «Про авторське право і суміжні права» (№10143), що нині зареєстрований у Верховній Раді України. Важливо зазначити, що цей законопроект було розроблено на виконання ст.ст. 157-192 гл.9 «Інтелектуальна власність» розділу IV угоди про асоціацію між Україною та СС. Це ще свідчить про необхідність його існування та у подальшому прийняття.

Слід вказати, що у новій редакції закону містяться переліки об'єктів авторського i суміжних прав, що відповідають потребам сьогодення. Більше того, законопроект №10143 передбачає вдосконалення норм щодо колективного управління правами правовласників на об'єкти авторського i суміжних прав. Запропоноване посилення відповідальності за порушення прав інтелектуальної власності [6].

Реалії сьогодення є такими, що 3 кожним роком в Україні стрімко розвивається наука i техніка, у зв'язку з чим з'являються нові об'єкти права інтелектуальної власності, питання охорони щодо яких не врегульовані в чинному національному законодавстві 3 огляду на його застарілість. Така ситуація, без сумніву, вимагає реакції з боку вітчизняного законодавця. Втім, необхідно обрати дещо іншу стратегію.
Перш за все, необхідно визначитися із системою і змістом законодавства про інтелектуальну власність. Адже ухвалення законів щодо кожного різновиду інтелектуальної діяльності, як це прийнято в Україні, продемонструвало свою недоцільність. Унаслідок цього - все більше дублюючих норм. Більше й суперечностей. Таких висновків ми дійшли на підставі системного аналізу положень законодавства, що складає систему інтелектуального права України.

Отже, варто погодитися з Г. О. Швець, О. О. Левінчук у тому, що наразі слід подумати про структуру законодавства України про інтелектуальну власність. При чому слушною видається позиція науковців, зміст якої зводиться до того, що це може бути як кодифікований акт про інтелектуальну власність (на прикладі досвіду зарубіжних країн), так і укрупнення законодавчих актів про інтелектуальну власність (наприклад, прийняття розгорнутого закону про авторське право і суміжні права) [14, с. 124]. Хоча нам більше імпонує ідея щодо прийняття розгорнутого закону про авторське право і суміжні права.

Крім того, перегляду потребують Концепція реформування державної системи правової охорони інтелектуальної власності в Україні та Національна стратегія розвитку сфери інтелектуальної власності в Україні.

Ще у 2016 році Кабінет Міністрів ухвалив Концепцію реформування державної системи правової охорони інтелектуальної власності в Україні. Передбачалася ліквідація Державної служби інтелектуальної власності та визначення національним органом у цій сфері державної організації, створеної на базі Укрпатенту, що належить до сфери управління Мінекономрозвитку.

Станом на 19.10.2019 ДСІВ ліквідовано, але повну реорганізацію сфери держуправління в цій сфері так і не закінчено. На сьогодні так і не впроваджено прозорої дворівневої структури державної системи правової охорони інтелектуальної власності.

При Мінекономрозвитку, що забезпечує формування та реалізацію державної політики у сфері інтелектуальної власності, так і не створено національного органу інтелектуальної власності, уповноваженого виконувати окремі публічні функції (владні повно- 
важення) з реалізації державної політики в зазначеній сфері.

Також було розроблено проект закону «Про внесення змін до деяких законодавчих актів України щодо вдосконалення державного управління сферою інтелектуальної власності». Однак системний аналіз положень цього законопроекту свідчить, що у його положеннях відсутня згадка про те, що Укрпатент є державним підприємством, виконуючим функції національного органу у сфері IB [7].

Суттєвих змін зазнала система колективного управління майновими авторськими та суміжними правами. У травні 2018-го було прийнято Закон «Про ефективне управління майновими правами правовласників у сфері авторського права і (або) суміжних прав», що диктує нові умови. Однак, на жаль, більшість можливостей, передбачених цим законом, так і не була практично реалізована [11].

Отже, можна з упевненістю заявити, що концепція реформування державної системи правової охорони інтелектуальної власності та стратегія розвитку інтелектуальної власності потребують перезавантаження. При чому у ході розробки нових документів необхідно керуватися, перш за все, моніторинговими даними щодо причин настільки низької ефективності впровадження реформ та розробленим Всесвітньою організацією інтелектуальної власності «Керівництвом з розробки стратегії в галузі інтелектуальної власності в країнах із перехідною економікою». Крім того, у процесі підготовки доцільно було 6 проаналізувати стратегії та концепції розвитку інших країн з метою з'ясування можливості запозичення позитивного досвіду та, у випадку виявлення такої можливості та доцільності, запозичити відповідний досвід.

Більш ефективних дій вимагає й напрямок розвитку права інтелектуальної власності в України, що полягає в гармонізації вітчизняного законодавства, що забезпечує правове регулювання інституту інтелектуальної власності з законодавством EC.

Відповідно до Угоди про поглиблену та всеохоплюючу зону вільної торгівлі між Україною та EC, яка є частиною Угоди про асоціацію і діє 31 січня 2016 року, передбачено реформування інтелектуального права України.

Це дозволить Україні повністю інтегруватися у світову торговельну систему, надалі залучати іноземні інвестиції та запобігти значним втратам 3 боку правовласників. Впровадження цих реформ 6 на порядку денному щорічного міждержавного Діллогу між Україною та EC щодо прав інтелектуальної власності.

Вищенаведене дає змогу зробити висновок, що наразі Україна повинна продемонструвати спроможність виконувати свої зобов'язання та залишатися надійним партнером. Необхідно якомога швидше прийняти та впровадити відповідні законопроекти, а також реформувати українську систему управління інтелектуальною власністю [1].

Втім, станом на кінець 2019 р. можна констатувати, що переважна більшість проблем у сфері інтелектуальної власності, 3 якими Україна входила в 2014 р., на сьогодні залишилася не розв'язаною [11]. Для вирішення зазначених проблем було розпочато низку дій, які, на жаль, не можна назвати завершеними.

У Европейському Союзі розчаровані повільним прогресом у просуванні реформ у цій сфері. Адже Уряд досі не подав на розгляд до Верховної Ради більшості законопроектів, які наша держава зобов'язалася прийняти відповідно до умов поглибленої та всеосяжної зони вільної торгівлі, вони й досі перебувають на розгляді в Мінекономрозвитку [7].

У зв'язку із цим важливого значення набуває потреба проаналізувати причини такого провалу реформ і розробити шляхи їхнього вирішення. 3 метою подальшого урахування отриманих даних у ході розробки нової стратегії розвитку інтелектуального права в Україні.

Хоча певні зрушення, звісно, є. Успішним можна назвати прийнятий Закон «Про державну підтримку кінематографії в Україні», в якому закріплено ефективні способи боротьби 3 порушеннями прав інтелектуальної власності в мережі Інтернет. 


\section{Дискусіі, обговорення, актуально}

Україна розглядає формування спеціалізованого суду з питань інтелектуальної власності як пріоритет і планує завершити відбір його суддів до кінця 2019 року. Одночасно триває створення нового офісу інтелектуальної власності, яке планується завершити у 2020 році.

Усе сказане дає змогу зробити висновок, що подальший розвиток інтелектуального права в Україні має відбуватися за трьома основними напрямками:

1) розробка нової Концепції реформування державної системи правової охорони інтелектуальної власності в Україні та Національної стратегії розвитку сфери інтелектуальної власності в Україні з урахуванням прорахунків та здобутків попередніх документів, а також міжнародних рекомендацій та зарубіжного досвіду;

2) подальше удосконалення національних нормативно-правових актів 3 питань інтелектуальної власності, узгодження їх положень між собою, усунення прогалин, приведення у відповідність до реалій сьогодення та потреб українського суспільства, систематизація положень національних нормативно-правових актів 3 питань інтелектуальної власності шляхом прийняття розгорнутого закону про авторське право і суміжні права;

3) подальше узгодження положень національних нормативно-правових актів 3 питань інтелектуальної власності із законодавством EC та приведення їх у відповідність до європейських, а також міжнародних норм та стандартів.

\section{Висновки з дослідження і перспек- тиви подальших розвідок у даному науковому напрямку}

Загалом, підсумовуючи вищесказане, можна зробити висновок, що право інтелектуальної власності в Україні наразі все ще перебуває на етапі формування.

Україна має достатній і потужний науково-технічний потенціал, який наразі треба привести у дію. Для цього необхідно виробити нові підходи до концептуальних положень законодавства України про інтелектуальну власність.
Насамкінець, слід зауважити, що питання виникнення та розвитку інтелектуального права в Україні потребує подальшого наукового дослідження у напрямку пошуку шляхів вдосконалення національного законодавства у цій сфері з метою удосконалення захисту прав інтелектуальної власності.

\section{Лiтература}

1. Ангел E. Інтелектуальна власність в Україні: реформи не поспішають. URL: https://zib.com.ua/ua/137236-sankcii_za_ porushennya_ avtorskih _ prav _ zrostut_ do_17000_grive.html (дата звернення: 21.10.2019).

2. Гелеверя С. М. Еволюційні передумови розвитку та сучасний стан системи інтелектуальної власності в Україні. Глобальні та національні проблеми економіки. 2018. №21. C. 142-147.

3. Глушко К. С. До питання про сутність поняття «інтелектуальна власність». Економіка: проблеми теорії та практика : збірник наукових пращь. Дніпропетровськ : ДНУ, 2007. №232. T.1. C. 56-62

4. Головкова О. М. Генезис правової охорони інтелектуальної власності. Форум права. 2008. № 1. С. 92-98.

5. Горнісевич А. М. Міжнародні стандарти захисту прав інтелектуальної власності. Наука та інновацій. 2011. Т. 7. № 3.C. 49-53.

6. Дзюбіна Є. Санкції за порушення авторського права й суміжних прав зростуть до 17000 гривень з конфіскацією. Закон $i$ бізнес. №14. 13.04.-19.04.2019. URL: https://zib. com.ua/ua/137236-sankcii_za_porushennya_ avtorskih _ prav _ zrostut_do_17000_grive. html (дата звернення: 20.10.2019).

7. Довідна О. В АПУ прогнозують, що українські підприємці будуть змушені відмовитися від охорони об'єктів IB через суттєве підвищення зборів. Закон $i$ бізнес. №38. 28.09-04.10.2019. URL: https:// zib.com.ua/ua/139373ukrainski_pidpriemci_ vidmovlyatimutsya_vid_ohoroni_ip_cherez. html (дата звернення: 20.10.2019).

8. Конституція України : закон України від 28.06.1996 р. Відомості Верховної Ради Украйни. 1996. № 30. Ст. 141. 
9. Концепція реформування державної системи правової охорони інтелектуальної власності в Україні схвалена розпорядженням КМУ від 1 червня 2016 р. № 402-p. URL: https://zakon.rada.gov.ua/ laws/show/402-2016-\%D1\%80 (дата звернення: 20.10.2019).

10. Ніколаєнко С. Проблеми законодавчого забезпечення та правозастосування щодо захисту прав інтелектуальної власності. Інтелектуальна власність. 2007. № 2. C. 4-14.

11. Нікулеско Д. Нової стратегії розвитку сфери інтелектуальної власності не буде? URL: https://dtua/macrolevel/novoyistrategiyi-rozvitku-sferi-intelektualnoyi- vlasnosti-ne-bude-307764_html (дата звернення: 21.10.2019).

12. Правова охорона інтелектуальної власності - атрибут державності цивілізованої країни. Наука та інноващиї. 2007. Т 3. № 4. C. 8-17.

13. Цивільний кодекс України : Закон України від 16.01.2003 р. № 435-IV. URL: https://zakon.rada.gov.ua/laws/card/435-15 (дата звернення: 19.10.2019).

14. Швець Г. О., Аевінчук О. О. Напрямки вдосконалення митного контролю при переміщенні через митний кордон товарів, які містять об'єкти права інтелектуальної власності. Теоретичні $i$ практичні аспекти економіки та інтелектуальної власності. 2012. №2. Том 1. С. 122-125. 